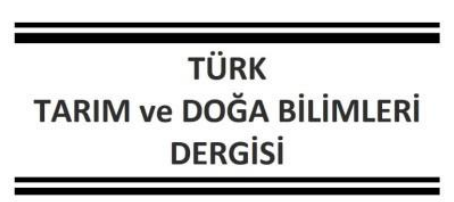

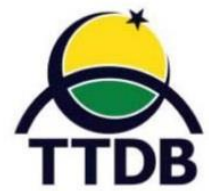

www.dergipark.gov.tr/turkjans Araştırma Makalesi

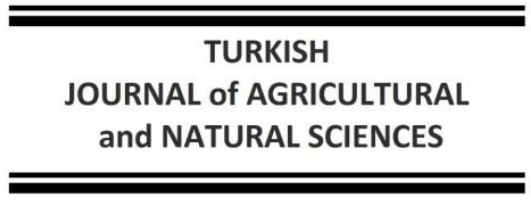

\title{
Kahramanmaraş Ekolojik Şartlarında Karadutun (Urmu dut) Morfolojik, Fenolojik ve Pomolojik Özelliklerinin Belirlenmesi
}

\author{
Mehmet SÜTYEMEZ* \\ Kahramanmaraş Sütçü İmam Üniversitesi, Ziraat Fakültesi, Bahçe Bitkileri Bölümü, Kahramanmaraş \\ *Sorumlu Yazar: sutyemez@ksu.edu.tr
}

Geliş Tarihi: 01.05.2021 Düzeltme Geliş Tarihi: 05.06.2021 Kabul Tarihi: 30.06.2021

\section{Öz}

Bu çalışma, Kahramanmaraş ilinde doğal olarak yetişen karadut (Morus nigra L., urmu dut) genotipi ve bu genotipten doku kültürü ile çoğaltılmış bitkilerin (5 bitki) morfolojik, fenolojik ve pomolojik özelliklerinin belirlenmesi amacıyla yapılmıştır. Klonal bitkilere ait morfolojik ölçümlerde ortalama gövde yüksekliklerinin 77$89 \mathrm{~cm}$, gövde kalınlıklarının 36-52.6 cm taç yüksekliklerinin 162.3-267.6 cm, taç genişliklerinin (çevre) 863.6$1263.3 \mathrm{~cm}$ arasında değiştiği belirlenmiştir. Yaprak ayası eninin 12.89-12.99 cm, yaprak boyunun 12.22-12.66 $\mathrm{cm}$, yaprak sap uzunluklarının 2.48-2.66 mm ve yaprak sap kalınlığına ait ortalama değerlerin ise 2.71-2.99 mm arasında değiştiği tespit edilmiştir. Ebeveyn bitkide ise bu özelliklere ait değerlerin sırasıyla $12.96 \mathrm{~cm}, 12.61 \mathrm{~cm}$, $2.61 \mathrm{~mm}, 2.77 \mathrm{~mm}$ olduğu belirlenmiştir. Ana genotip dahil tüm bitkilerde tomurcuklar 4-6 Nisan döneminde patlarken, çiçek salkımlarının 9-13 Nisan döneminde görülmeye başladığı gözlenmiştir. Hasat dönemlerinin ise 20 Mayısta başlayıp Ağustos 25'e kadar devam ettiği belirlenmiştir. Ebeveyne ait meyve ağılıklarının ortalaması $3.65 \mathrm{~g}$ olarak hesaplanmıştır. Klon bitkilerde ise ortalama meyve ağırlıkları $3.28 \mathrm{~g}$ ile $3.96 \mathrm{~g}$ değerleri arasında bulunmuştur. Meyve örneklerinde yapılan diğer ölçümlerde ortalama pH \%3.36-3.44, SÇKM \%15.20-15.97, TEA değerlerinin ise \%0.22-0.24 arasında değiştiği belirlenmiştir. Kuru maddenin \%18.10-18.92, kül miktarının \%3.15-3.25, protein oranının \%3.19-3.92, ham yağın \%4.96-5.72, toplam şekerin ise \%14.81-15.44 arasında değiştiği belirlenmiştir. Renk değerlerinin L:18.47-18.97, a:5.11-5.72, b:5.83-5.93 arasında değiştiği bulunmuştur. Genel olarak değerlendirildiğinde doku kültürü ile çoğaltılmış bitkiler ile ana ebeveyn bitki arasında bitkisel özellikler ve pomolojik özelliklerin çok yakın değerlere sahip olduğu görülmüştür.

Anahtar kelimeler: Karadut, morfoloji, fenoloji, pomoloji, kimyasal içerik.

\section{Determination of Morphological, Phenological and Pomological Properties of Black Mulberry (Urmu mulberry) in Kahramanmaraş Ecological Conditions}

\begin{abstract}
This study was carried out to determine the genotype of black mulberry (Morus nigra L., urmu mulberry) growing naturally in Kahramanmaraş province and the morphological, phenological and pomological characteristics of the plants (5 plants) grown by tissue culture from this genotype. In the morphological measurements of clonal plants, it was determined that the average trunk height varied between $77-89 \mathrm{~cm}$, trunk thickness 36-52.6 cm, crown heights 162.3-267.6 cm, crown widths (circumference) 863.6-1263.3 cm. It was determined that leaf blade width varied between $12.89-12.99 \mathrm{~cm}$, leaf length $12.22-12.66 \mathrm{~cm}$, leaf stem length $2.48-2.66 \mathrm{~mm}$ and mean values of leaf stem thickness between $2.71-2.99 \mathrm{~mm}$. In the parent plant, the values of these features were determined to be $12.96 \mathrm{~cm}, 12.61 \mathrm{~cm}, 2.61 \mathrm{~mm}, 2.77 \mathrm{~mm}$, respectively. It was observed that in all plants including the main genotype, the buds burst during the 4-6 April period, while the inflorescences began to appear in the 9-13 April period. It has been determined that the harvest periods start on May 20 and continue until August 25. The average weight of fruit belonging to the parent was calculated as $3.65 \mathrm{~g}$. In clone plants, the average fruit weight was found between $3.28 \mathrm{~g}$ and $3.96 \mathrm{~g}$. In other measurements made in fruit samples, it was determined that the average $\mathrm{pH}$ was $3.36-3.44 \%$, soluble solids content 15.20 $15.97 \%$, and Titratable acidity values varied between $0.22-0.24 \%$. It was determined that dry matter varied
\end{abstract}


between 18.10-18.92\%, ash amount 3.15-3.25\%, protein ratio 3.19-3.92\%, crude oil 4.96-5.72\% and total sugar between 14.81-15.44\%. Color values were found to vary between L: 18.47-18.97, a: 5.11-5.72, b: 5.83-5.93. When evaluated in general, it has been observed that the vegetative and pomological properties have very close values between the plants propagated by tissue culture and the parent plant.

Key words: Black mulberry, morphology, phenology, pomology, chemical content.

\section{Giriş}

Çin, Kore, Japonya dutun gen merkezleri olarak bilinmektedir. Dut hem farklı iklim-toprak şartlarına uyum yeteneğinin yüksek olması, hem de genetik zenginliğinden dolayı ılıman ve subtropik iklim kuşaklarında yetiştirilebilmektedir (Vavilov, 1926; Bellini ve ark., 2000). Urticales takımının Moreceae familyasının Morus cinsine dâhil bir meyve türü olan dutun, sıcak ve tropik bölgelere yayılmış 73 cinsi ve 100 kadar türü olduğu bilinmektedir. Karadut ise (Morus nigra L.) dünyanın birçok yerinde doğal yetişme alanı bulmuş dut türlerinden birisidir (De Candolle, 1967; Rahman ve Khanom, 2013; Chen ve ark., 2015).

Ağaçlarının nemli topraklarda büyümeleri yavaş olmasına rağmen uyum yetenekleri yüksek olup kökleri $15 \mathrm{~m}$ derine kadar ulaşabilmektedir. Diğer dut türlerine göre Karadut'a ait ağaçların bodur olduğu ve ortalama 6-9 m'ye kadar boylanabildiği bilinmekle birlikte 30 m'ye kadar boylanmanın da olduğu bildirilmiştir. Gövdesi koyu gri renkli, yaprakları ise kalın pürüzlü ve koyu yeşildir. Karadut meyveleri çoklu meyve (multiple) yapısında olup iki ucu basık oval-silindir şeklindedir. Kendine has bir aromaya sahip olan karadut meyveleri siyahımsı mor renkli, etli, sulu ve mayhoştur (GM de Rougemont, 1989; Pool, 1966; Roger, 2002; Anonim, 2002; Koyuncu ve Vural, 2003).

Stoner ve ark., (1999) yüksek antosiyanin içeren siyah ahududundan elde edilen ekstrakların ağız, gırtlak, yemek borusu, mide ve kolon gibi sindirim sistemi gibi kanser tiplerinde koruyucu ve tedavi edici özelliklerinin olduğunu bildirmişlerdir. Ülkemizde de halk arasında karadut meyvesinin ağız ve boğazdaki hastalıklara bilhassa bebeklerde görülen pamukçuğa karşı olumlu etkisinin olduğu söylenmektedir (Polat, 2013). Özgen ve ark., (2009) ise ülkemizin hemen her bölgesinde yetişebilen karadutun siyah ahudududan daha fazla antosiyanin içerdiğini bildirilmiştir. Karadutlarda, siyanidin 3-glukozit en fazla bulunan antosiyanindir. Karadutlardaki antosiyaninlerin 30 ${ }^{\circ} C^{\prime}$ de uzun süre (80 gün) kalabildiği için gıdalarda renk maddesi olarak kullanılabileceği belirtilmiştir (Mazza ve Miniati, 1993). Üzümsü meyveler içerdikleri yüksek miktardaki antosiyanin, fenolik maddeler ve askorbik içerikleri sayesinde yüksek antioksidan kapasitelerine sahiptir (Özgen ve ark., 2009). Morus nigra'nın koyu kırmızı meyveleri, insan sağlığına olumlu katkılarının yanında, hastalıkların önlenmesi ve tedavisi açısından önemli kimyasal maddeler içermektedir (Okatan, 2018).

Ülkemizde dut meyveleri taze veya kurutularak tüketilebildiği gibi pekmez, sirke, pestil ve köme şeklinde işlenerek de değerlendirilmektedir. Bazı ülkelerde ise taze dut meyveleri, pay, reçel ve dut şarabı olarak kullanılırken kurutulmuş meyveleri kıvam artırıcı olarak ekmek, çörek ve pudinglere eklenmektedir (Erdoğan ve Pırlak, 2005). Ayrıca taze dut meyvesi geleneksel olarak tüketilmekte ve son yıllarda dutun meyve suyu, bir sağlık içeceği olarak ticari bir şekilde üretilmektedir. Koruyucu madde eklenmeden dut meyve suyu, soğuk depo şartlarında 12 aya kadar tazeliğini koruyabilmektedir (Huo, 2004).

Bu çalışma, Kahramanmaraş ekolojisinde yetişen urmu dut genotipinin ve bu genotipten doku kültürü ile elde edilmiş klon bitkilerinde, bazı morfolojik, fenolojik, pomolojik özellikler ve kimyasal içerikleri belirlemek amacıyla yapılmıştır.

\section{Materyal ve Metot}

Bu çalışma, 2013-2021 yılları arasında yürütülmüş olup, Kahramanmaraş Gafarlı bölgesinde doğal olarak yetişen karadut (urmu dut) genotipi (şahit) ve bu genotipten Nas (2013) tarafından doku kültürü ile çoğaltılmış ve 2013 yılında tesis edilmiş klon parselindeki 5 bitki kullanılmıştır. Araştırmada her ağacı temsil edecek sayıda 30'ar adet yaprak ve meyve örneği alınmıştır. Çalışmada bitkilere ait 2018 (6. yaş), 2019 (7. yaş), 2020 (8. yaş) olmak üzere 3 yıllık veriler ve ortalamaları sunulmuştur.

\section{Morfolojik özelliklerin belirlenmesi}

Bahçe tesisinden itibaren olmak üzere klon bitkiler üzerinde her yıl morfolojik ve fenolojik gözlemler yapılmıştır. Çalışmada tam verim çağı olarak kabul edilen 6 . yaş sonrası bulgular üzerinden alınan sonuçlar sunulmuştur.

Bitkilerin ilk meyve gösterme yaşları, gövde yüksekliği; toprak seviyesi ile ana dalların 
çıktığı nokta arası şerit metre yardımıyla cm cinsinden ölçülmüştür. Gövde kalınlığı; gövdenin orta noktası işaretlenip cm cinsinden hesaplanmıştır. Ağacın taç yüksekliği ve çevresi şerit metre yardımıyla metre cinsinden tespit edilmiştir. Yaprak eni, yaprak boyu, yaprak sap uzunluğu ve yaprak sap kalınlığı her ağaçtan tesadüfi olarak alınan 20 adet yaprak örneğinin $0.01 \mathrm{~mm}$ hassasiyetli dijital kumpas ile ölçülerek ortalamaları hesaplanmıştır (Erdem, 2015).

\section{Fenolojik özelliklerin belirlenmesi}

Karaduttan 2018, 2019 ve 2020 yılı vejetasyon döneminde gün aşırı olmak üzere fenolojik gözlemler yapılmıştır. Tomurcukların patlaması; tomurcuktan çıkan ilk yaprakların toplu halde belirgin şekilde görüldüğü dönemdir. İlk çiçeklenme zamanı; çiçeklerin yaprakların arasından belirginleşerek görülmeye başladığı tarih olarak kabul edilmiştir (Erdem, 2015). Hasat sonu; vejetasyon süresinde son meyvelerin olgunlaştığı zamandır (Polat, 2013).

\section{Pomolojik analizler}

Karaduttan alınan 20'şer meyvede en, boy, sap uzunluğu, sap boyu $0.01 \mathrm{~mm}$ hassasiyetli dijital kumpas yardımı ile ölçülmüştür. Meyveler 0.01 g'a duyarlı hassas terazi de tartılarak ağılıkları g cinsinden belirlenmiştir (Cemeroğlu, 1992).

Karadutlarda $\mathrm{pH}$ tayini; meyve suyunda 3 yinelemeli olarak cam elektrotlu pH metre ile ölçülerek yapılmıştır. Suda çözünen kuru madde (briks) miktarı; dut meyveleri homojenize edildikten sonra saf suya göre kalibre edilmiş el refraktometre ile suda çözünebilir kuru madde miktarı ${ }^{\circ}$ Brix olarak ölçülmüş ve sonuçlar \% olarak ifade edilmiştir (Cemeroğlu, 1992). Asitlik tayini (titrimetrik); taze dut meyvelerinde doğrudan meyve suyu sıkıldıktan sonra, meyve suyundan 5 $\mathrm{ml}$ alınarak $0.1 \mathrm{~N} \mathrm{NaOH}$ çözeltisi ile ve bir pH metre yardımıyla titrasyon işlemi gerçekleştirilmiştir. Titrasyon işlemi 3 tekerrür olarak yapılmış ve titrasyon sonuçlarının ortalaması alınarak \% olarak hesaplanmıştır (Cemeroğlu, 1992). Toplam kuru madde oranı TS 2131 ISO 928 standardına göre toplam kül tayini yapılarak kuru madde miktarı \% olarak hesaplanmıştır. Dut örneklerinin protein tayini Kjeldahl methodu kullanılarak \% olarak hesaplanmıştır. Ham yağ tayini kuru madde üzerinden TS 6317 standardına göre yapılmıştır. Toplam şeker içeriği volumetrik Lane-Eynon metodu kullanılarak \% olarak hesaplanmıştır (Cemeroğlu, 1992).

Renk tayini; meyvelerin renk değerinin ölçümünde Minolta marka CR300 model renk ölçer kullanılarak gerçekleştirilmiştir. Renk ölçer ile materyalin Hunter Lab Chromameter renk değerleri olan $L, a, b$ değerleri belirlenmiştir. Bu değerler; L: meyvelerin parlaklık değerlerini ifade ederken 0-100 arasında değişim göstermektedir. L değeri 0 olduğunda ürünlerin rengi siyah, yani yansımanın olmadığını ifade ederken, $L$ değeri 100 olduğunda ise renk değerinin beyaz, yani yansımanın tam olduğunu göstermektedir. Renk değerlerinden olan a: kırmızı-yeşil, b: sarı-mavi renkleri ifade ederken sırasıyla + , - işaretlerini alır. Renk değerleri $a=0$ ve $b=0$ olduğu durumda ise meyvelerin renklerinin gri olduğunu ifade etmektedir (McGuire, 1992). Kroma değeri (C) $=(a 2$ + b2)1/2 eşitliği ile hesaplanmıştır (Lopez ve ark., 2013). Meyvelere ait rengin tonunu ifade ederken solgun renklerde düşük, canlı renklerde ise yüksek değerler almaktadır. Hue açısı $h^{\circ}=\tan -1 \quad(b / a)$ eşitliği kullanılarak hesaplanmıştır. Renk açısı değerinin $360^{\circ}$ lik bir renk radyantında her açıya karşılık gelen renklerin görülmesini kolaylaştırır. $0^{\circ}$ kırmızı, $90^{\circ}$ sarı, $180^{\circ}$ yeşil ve $270^{\circ}$ ise ürünün mavi renkte olduğunu ve bu açı değerlerinin aralarına denk gelen kısımlarda ara renklerin oluştuğu görülmektedir.

\section{Bulgular ve Tartışma Morfolojik özelliklerin belirlenmesi}

Ebeveyn bitki ve klon bitkiler üzerinde 3 yıl üst üste elde edilen sonuçlar çalışmada sunulmuştur (Çizelge 1-7). Üzerlerinde çalışılan bitkilerin "gövde yüksekliği, gövde kalınlığı, ağacın taç yüksekliği ve genişliği, yaprak eni, yaprak boyu, yaprak sap uzunluğu ve yaprak sap kalınlığı gibi morfolojik özelliklere ait bulgular Çizelge 1 ve 2 'de verilmiştir.

Klonal bitkilerin (ağaçların) ortalama gövde yüksekliklerinin 3. yıl sonunda $77 \mathrm{~cm}$ ile $89 \mathrm{~cm}$, arasında, gövde kalınlıklarının ise sırasıyla $36 \mathrm{~cm}$ ile $52.6 \mathrm{~cm}$ arasında olduğu ölçülmüştür. Ağaçlarda ortalama taç yüksekliklerinin $162.3-267.6 \mathrm{~cm}$, taç genişliklerinin (çevresinin) ise $863.6-1263.3 \mathrm{~cm}$ arasında değiştiği belirlenmiştir (Çizelge 1). Klonal bitkilerde gelişme performanslarının genelde birbirine yakın olduğu görülmektedir.

Üzerlerinde çalışılan bitkilerde ortalama, yaprak en değerlerinin $12.89-12.99 \mathrm{~cm}$, yaprak boy uzunluklarının ise $12.22 \mathrm{~cm}$ ile $12.66 \mathrm{~cm}$ arasında olduğu ölçülmüştür. Ebeveyn bitkide ise bu özelliklere ait değerlerin sırasıyla $12.96 \mathrm{~cm}$ ve 12.61 $\mathrm{cm}$ olduğu belirlenmiştir (Çizelge 2 ).

Yapraklarda ortalama sap uzunluklarının klon bitkilerde $2.48 \mathrm{~mm}$ ile $2.66 \mathrm{~mm}$ arasında; sap kalınlık değerlerinin ise $2.71 \mathrm{~mm}$ ile $2.99 \mathrm{~mm}$ arasında olduğu belirlenmiştir. Ebeveyn bitkide sap uzunluk ve yaprak sap kalınlık değerlerinin ise $2.61 \mathrm{~mm}$ ve $2.77 \mathrm{~mm}$ olduğu bulunmuştur (Çizelge 2). Bitkisel özellikler yönüyle klonal bitkilerin birbirine yakın gelişme performansı gösterdikleri ve 
yaprak özelliklerine ait değerlerin de birbirine oldukça yakın olduğu görülmektedir (Çizelge 1 , Çizelge 2).

Erkaleli ve ark., (2016) tarafından Uşak ili Ulubey ilçesindeki 15 farklı karaduta (Morus nigra L.) ait ağaçların gövde çevreleri $61-187 \mathrm{~cm}$, yaprak eni 8.1-11.9 mm, uzunluğu 8.7-12.1 mm, yaprak sapı uzunluğu 1.8-2.8 mm olarak bulunmuştur. Antalya'da karadutlar üzerinde yapılan başka bir çalışmada ise yaprakların en, boy ve sap uzunluk değerlerinin sırasıyla $9.3-14.5 \mathrm{~cm}, 10.7-15.7 \mathrm{~cm}$, 2.7-3.8 cm arasında olduğu bildirilmiştir (Uzun ve Bayır, 2009).

Çizelge 1. Bitkisel (ağaç) özelliklere ait sonuçlar

\begin{tabular}{|c|c|c|c|c|c|c|c|c|c|c|c|c|c|c|c|c|c|}
\hline \multirow{3}{*}{ Bitkiler } & \multirow{3}{*}{$\begin{array}{c}\text { ilk } \\
\text { Meyve } \\
\text { Yaşı }\end{array}$} & \multicolumn{8}{|c|}{ Gövde } & \multicolumn{8}{|c|}{ Taç } \\
\hline & & \multicolumn{4}{|c|}{ Yüksekliği (cm) } & \multicolumn{4}{|c|}{ Kalınlığı (cm) } & \multicolumn{4}{|c|}{ Yüksekliği (cm) } & \multicolumn{4}{|c|}{ Genişliği (cm) } \\
\hline & & 2018 & 2019 & 2020 & Ort. & 2018 & 2019 & 2020 & Ort. & 2018 & 2019 & 2020 & Ort. & 2018 & 2019 & 2020 & Ort. \\
\hline 1 & 3 & 75 & 75 & 75 & 77.0 & 35 & 37 & 38 & 36 & 193 & 196 & 208 & 162.3 & 902 & 914 & 926 & 863.6 \\
\hline 2 & 3 & 77 & 78 & 77 & 77.6 & 49 & 53 & 55 & 52.6 & 261 & 269 & 261 & 226 & 1213 & 1276 & 1301 & 1263.3 \\
\hline 3 & 4 & 87 & 88 & 88 & 89.0 & 34 & 36 & 39 & 36 & 220 & 227 & 238 & 267.6 & 918 & 954 & 975 & 949 \\
\hline 4 & 3 & 76 & 76 & 76 & 78.6 & 36 & 37 & 39 & 37.3 & 230 & 234 & 237 & 233.6 & 955 & 982 & 997 & 978 \\
\hline 5 & 3 & 77 & 80 & 81 & 79.3 & 35 & 38 & 40 & 37.3 & 228 & 230 & 233 & 230.3 & 913 & 940 & 962 & 938.3 \\
\hline Ebeveyn & - & 125 & 125 & 125 & 125 & 86 & 86 & 86 & 86 & 274 & 274 & 274 & 274 & 7480 & 7534 & 7570 & 7496 \\
\hline
\end{tabular}

Çizelge 2. Bitkisel (yaprak) özelliklere ait sonuçlar

\begin{tabular}{|c|c|c|c|c|c|c|c|c|c|c|c|c|c|c|c|c|}
\hline \multirow{3}{*}{ Bitkiler } & \multicolumn{16}{|c|}{ Yaprak } \\
\hline & \multicolumn{4}{|c|}{ En $(\mathrm{cm})$} & \multicolumn{4}{|c|}{ Boy $(\mathrm{cm})$} & \multicolumn{4}{|c|}{ Sap Uzunluğu (cm) } & \multicolumn{4}{|c|}{ Sap Kalınlığı (cm) } \\
\hline & 2018 & 2019 & 2020 & Ort. & 2018 & 2019 & 2020 & Ort. & 2018 & 2019 & 2020 & Ort. & 2018 & 2019 & 2020 & Ort. \\
\hline 1 & 12.99 & 13.00 & 13.00 & 12.99 & 12.68 & 12.65 & 12.66 & 12.66 & 2.60 & 2.61 & 2.60 & 2.60 & 2.71 & 2.73 & 2.71 & 2.71 \\
\hline 2 & 12.93 & 12.94 & 12.94 & 12.93 & 12.22 & 12.26 & 12.30 & 12.26 & 2.68 & 2.65 & 2.66 & 2.66 & 3.01 & 2.98 & 2.99 & 2.99 \\
\hline 3 & 12.92 & 12.92 & 12.93 & 12.92 & 12.23 & 12.26 & 12.29 & 12.26 & 2.47 & 2.48 & 2.49 & 2.48 & 2.69 & 2.72 & 2.70 & 2.70 \\
\hline 4 & 12.88 & 12.91 & 12.90 & 12.89 & 12.20 & 12.23 & 12.23 & 12.22 & 2.51 & 2.49 & 2.51 & 2.50 & 2.70 & 2.71 & 2.73 & 2.71 \\
\hline 5 & 12.91 & 12.90 & 12.91 & 12.90 & 12.27 & 12.28 & 12.28 & 12.27 & 2.56 & 2.58 & 2.59 & 2.57 & 2.72 & 2.71 & 2.71 & 2.71 \\
\hline Ebeveyn & 12.95 & 12.98 & 12.97 & 12.96 & 12.60 & 12.62 & 12.62 & 12.61 & 2.61 & 2.63 & 2.61 & 2.61 & 2.78 & 2.75 & 2.79 & 2.77 \\
\hline
\end{tabular}

\section{Fenolojik özelliklerin belirlenmesi}

Fenolojik gözlem kriteri olan tomurcukların patlama dönemi, çiçeklenme ve ilk- son hasat tarihleri Çizelge 3'te verilmiştir. Yıllara göre değişmek üzere Nisan ayı (4-6) başında patlayan tomurcuklardan sonra bir-iki hafta içerisinde yapraklar fare kulağı safhasına ulaşmış ve tam yapraklanma ise Nisan ayı sonunda gerçekleşmiştir. Çiçek salkımları 9-13 Nisan tarihleri arasında görülmeye başlarken, hasat döneminin ise Mayıs ayının 2. yarısında başlayıp Ağustos ayı ortalarına kadar devam ettiği gözlemlenmiştir. Ana ebeveyn bitkide, tomurcukların 5 Nisan'da patladığı, 10 Nisan'da çiçek salkımlarının görüldüğü ve hasadın ise 18 Mayıs- 21 Ağustos'a kadar devam ettiği belirlenmiştir. Koyuncu, (2004) ülkemizin Akdeniz Bölgesinde yer alan Sütcüler ilçesindeki 10 farklı karadut genotipinde yaptığı bir çalışmada hasat dönemini Haziran ayı ve Eylül ayının ilk haftası arasında olduğunu bildirmiştir.

Çizelge 3. Fenolojik gözlemlere ait sonuçlar

\begin{tabular}{cccccccccccc}
\hline \multirow{2}{*}{ Bitkiler } & \multicolumn{3}{c}{ Tomurcukların Patlama } \\
Dönemi & \multicolumn{4}{c}{ Çiçek Salkımlarının Görülme } & \multicolumn{3}{c}{ Hasat Tarihi (ilk-son) } \\
& 1.yıl & 2.yıl & 3.yıl & Ort. & 1.yıl & 2.yıl & 3.yıl & Ort. & 1.yıl & 2.yıl & 3.yıl \\
\hline $\mathbf{1}$ & $2 / 4$ & $6 / 4$ & $5 / 4$ & $4 / 4$ & $08 / 4$ & $11 / 4$ & $09 / 4$ & $09 / 4$ & $23 / 5-17 / 8$ & $26 / 5-20 / 8$ & $24 / 5-15 / 8$ \\
$\mathbf{2}$ & $2 / 4$ & $7 / 4$ & $8 / 4$ & $6 / 4$ & $10 / 4$ & $12 / 4$ & $11 / 4$ & $13 / 4$ & $16 / 5-12 / 8$ & $17 / 5-14 / 8$ & $14 / 5-12 / 8$ \\
$\mathbf{3}$ & $3 / 4$ & $7 / 4$ & $6 / 4$ & $5 / 4$ & $10 / 4$ & $15 / 4$ & $15 / 4$ & $13 / 4$ & $24 / 5-16 / 8$ & $01 / 6-20 / 8$ & $30 / 5-16 / 8$ \\
$\mathbf{4}$ & $4 / 4$ & $7 / 4$ & $6 / 4$ & $6 / 4$ & $09 / 4$ & $13 / 4$ & $15 / 4$ & $11 / 4$ & $14 / 5-15 / 8$ & $15 / 5-18 / 8$ & $11 / 5-14 / 8$ \\
$\mathbf{5}$ & $2 / 4$ & $6 / 4$ & $6 / 4$ & $5 / 4$ & $09 / 4$ & $12 / 4$ & $11 / 4$ & $11 / 4$ & $15 / 5-11 / 8$ & $16 / 5-22 / 8$ & $13 / 6-15 / 8$ \\
Ebeveyn & $5 / 4$ & $7 / 4$ & $7 / 4$ & $6 / 4$ & $10 / 4$ & $11 / 4$ & $10 / 4$ & $10 / 4$ & $18 / 5-17 / 8$ & $22 / 5-21 / 8$ & $13 / 5-16 / 8$ \\
\hline
\end{tabular}

\section{Pomolojik analizler}

Urmu dut genotipi ve bu genotipten klon olarak çoğaltılan bitkilerden elde edilen meyvelerin ağırlığı, eni, uzunluğu, sap kalınlığı, sap uzunluğu gibi pomolojik analizlerin yanında $\mathrm{pH}$ tayini, SÇKM, TEA, kuru madde oranı, kül tayini, protein, ham yağ, toplam şeker, renk değerlerine ait bulgular Çizelge 4-7'de verilmiştir.
Meyveler tam olgun dönemde toplanmış ve pomolojik ölçümler yapılmıştır. Klonal bitkilere ait meyve ağırlık ortalamaları 3.28-3.96 g arasında değişirken, meyve en değerlerinin 15.13-16.76 mm, meyve boylarının ise 17.66-21.24 $\mathrm{mm}$ arasında değiştiği belirlenmiştir. Ebeveyn bitkinin meyve ağırlığının $3.65 \mathrm{~g}$, meyve en değerinin $16.34 \mathrm{~mm}$ ve meyve boy değerinin ise $20.05 \mathrm{~mm}$ olduğu görülmektedir. Her 5 ağaçtan alınan meyvelerde, 
meyve sap uzunluklarının 1.62-2.01 mm, arasında ve sap kalınlık değerlerinin ise $1.06-1.10 \mathrm{~mm}$, arasında değiştiği kayıt altına alınmıştır (Çizelge 4).

Türkiye'de farklı bölgelerdeki kara dutların meyve ağırlıklarının, meyve enlerinin, meyve uzunluklarının değerleri sırasıyla 2.5-5.4 g, 13.03$19.6 \mathrm{~mm}$ ve $16.70-25.4 \mathrm{~mm}$ arasında olduğunu belirlemişlerdir (Uzun ve Bayır, 2009; Erkaleli ve Dalkılıç, 2016). Ülkemizin Akdeniz Bölgesinde yer alan Sütcüler ilçesindeki karadutların meyve ağırlığı, meyve çapı ve meyve uzunluğunun sırasıyla 3.11-4.49 g, 15.34-16.29 mm ve 22.33-25.15 mm olduğunu bildirmiştir (Koyuncu, 2004). Hosseini ve ark. (2018) tarafından karadutta yapılan bir çalışmada meyve ağırlıklarının 1.79 ile $5.69 \mathrm{~g}$ değerleri arasında değiştiğini bildirmişlerdir.

Karadut meyvelerinden çıkarılan sularda 3 tekrarlı olarak pH metre ile ölçüm yapılmıştır.

Klonal bitkilere ait ortalama $\mathrm{pH}$ değerleri 3.36-3.44 arasında değişirken, ortalama SÇKM (\%) değerleri \%15.20-\%15.97 arasında, ortalama TEA (\%) değerlerinin ise \%0.22-\%0.24 arasında değiştiği belirlenmiştir (Çizelge 5). Ebeveyn bitkinin $\mathrm{pH}$ değeri 3.40, SÇKM değeri \%15.97, TEA değeri \%0.22 olduğu görülmektedir (Çizelge 5). Klonal dut genotiplerinde ortalama değerler yönünden, kuru madde oranlarının \%18.10-\%18.92 arasında, kül oranlarının \%3.15-\%3.25 arasında, protein oranlarının 3.19-3.92 arasında, ham yağ oranlarının \%4.96-\%5.72 arasında, toplam şeker oranlarının ise \%14.81-\%15.44 arasında değişim gösterdiği belirlenmiştir (Çizelge 6). Klonal genotiplere ait olgunlaşmış meyvelerde renk değerleri $L=18.47$ 18.97 arasında, $a=5.10-5.72$ arasında, $b=5.83-5.93$ arasında, Kroma değerleri 7.42-9.32 arasında, Hue değerleri ise 47.28-49.28 arasında değişim gösterirken, ebeveyn bitkide $\mathrm{L}=18.56, \mathrm{a}=5.17$, $b=5.92$, Kroma 7.63, Hue 47.57 ve toplam şeker oranı ise \%15.26 olarak belirlenmiştir (Çizelge 6-7).
Güven ve Başaran (1979) Çanakkale yöresindeki karadutlarda yaptıkları bir çalışmada SÇKM \%14.20, pH 3.70 ve TEA \%1.48 olarak belirlemişlerdir. Edremit ve Gevaş yöresinde yapılan başka bir çalışmada ise karadutlarda SÇKM değeri 16.62-19.16 pH değeri 6.2-7.4 ve TEA değeri 0.167-0.264 bulunmuştur (Çam, 2000). Akbulut ve ark. (2006) Gaziantep, Konya ve Malatya illerindeki karadutta yaptıkları bir çalışmada, SÇKM \%29.5, pH 5.41, toplam asitlik oranının \%0.27 olduğu bildirilmiştir. Uzun ve Bayır (2009) tarafından karadutlarda yapılan bir çalışmada ise SKÇM, $\mathrm{pH}$ ve TEA değerlerinin sırasıyla \%15.6-17.6, 3.3-3.8 ve \%1.94-2.23 arasında değiştiğini bildirmiştir. Uşak ili Ulubey ilçesinde doğal olarak yetişen 15 farklı karadut meyvelerinin suda çözülebilir kuru madde (SÇKM) miktarı $11.55-19.04^{\circ}$ Brix, pH değeri 3.634.18 ve titre edilebilir asit miktarı (TEA) sitrik asit olarak \%1.37-2.24 g/100 ml tespit edilmiştir (Erkaleli ve Dalkılıç, 2016). Bu beş çalışmaya göre çalışmada elde ettiğimiz SÇKM değerleri paralellik gösterirken TEA değerleri Çam (2000), Akbulut ve ark.'nın (2006) yaptıkları çalışmalar ile benzer, diğer çalışmalardan ise düşük bulunmuştur. $\mathrm{pH}$ değerleri açısından bu çalışmanın sonuçları Çam (2000), Akbulut ve ark.'nın (2006) çalışmasından daha düşük, diğer çalışmalar ile ise benzer olduğu görülmüştür.

Akbulut ve ark.'nın (2006) karadutta yaptıkları bir çalışmada, renk ölçüm değerleri $L=10.80, a=0.47$ ve $b=0.42$ olarak kaydedilmiştir. Uşak ili Ulubey ilçesinde 15 farklı karadut genotipinde renk $L=15.21-21.45, \quad a=6.13-21.69$, $b=2.86-9.44$, kroma 6.76-23.67, hue 1.98-2.70 olarak belirlenmiştir (Erkaleli ve Dalkılıç, 2016).

Yaptığımız çalışmada elde edilen $L, a, b$ ve kroma değerlerinin diğer çalışma sonuçları ile benzer olduğu görülürken, hue değerleri yönünden farklı olduğu dikkat çekici olarak değerlendirilmiştir.

Çizelge 4. Belirlenen dut genotiplerinde pomolojik analizlere ait sonuçlar

\begin{tabular}{|c|c|c|c|c|c|c|c|c|c|c|c|c|c|c|c|c|c|c|c|c|}
\hline \multirow[t]{2}{*}{ Bitkiler } & \multicolumn{3}{|c|}{$\begin{array}{l}\text { Meyve ağırlı̆ı } \\
\text { (g) }\end{array}$} & \multicolumn{4}{|c|}{$\begin{array}{l}\text { Meyve eni } \\
(\mathrm{mm})\end{array}$} & \multicolumn{4}{|c|}{$\begin{array}{c}\text { Meyve boyu } \\
(\mathrm{mm})\end{array}$} & \multicolumn{4}{|c|}{$\begin{array}{l}\text { Meyve sap uzunluğu } \\
(\mathrm{mm})\end{array}$} & \multicolumn{5}{|c|}{$\begin{array}{l}\text { Meyve sap kalınlığı } \\
(\mathrm{mm})\end{array}$} \\
\hline & 1.yll & 2.yil & 3.yll & Ort. & 1.yil & 2.yil & 3.yll & ort. & 1.yıl & 2.yil & 3.yil & Ort. & 1.yll & 2.yil & 3.yil & Ort. & 1.yll & 2.yil & 3.yil & Ort. \\
\hline 1 & 3.40 & 3.46 & 3.48 & 3.44 & 16.14 & 16.22 & 16.24 & 16.20 & 19.66 & 19.70 & 19.71 & 19.69 & 1.62 & 1.62 & 1.63 & 1.62 & 1.11 & 1.09 & 1.10 & 1.10 \\
\hline 2 & 3.97 & 3.95 & 3.96 & 3.96 & 16.77 & 16.71 & 16.80 & 16.76 & 21.26 & 21.24 & 21.24 & 21.24 & 2.04 & 2.02 & 1.99 & 2.01 & 06 & 1.07 & 1.07 & 1.06 \\
\hline 3 & 3.25 & 3.27 & 3.34 & 3.28 & 15.11 & 15.09 & 15.20 & 15.13 & 17.70 & 17.64 & 17.65 & 17.66 & 1.59 & 1.5 & 1.62 & 1.59 & 1.10 & 1.02 & 1.08 & 1.06 \\
\hline 4 & 3.52 & 3.57 & 3.62 & 3.57 & 16.21 & 16.26 & 16.30 & 16.25 & 19.70 & 19.73 & 19.73 & 19.72 & 1.60 & 1.61 & 1.61 & 1.60 & 1.10 & 1.10 & 1.09 & 1.09 \\
\hline 5 & 3.62 & 3.65 & 3.66 & 3.64 & 16.33 & 16.34 & 16.39 & 16.35 & 19.74 & 19.77 & 19.80 & 19.77 & 1.63 & 1.6 & 1.62 & 1.62 & 1.08 & 1.11 & 1.08 & 1.09 \\
\hline Ebeveyn & 3.62 & 3.68 & 3.65 & 3.65 & 16.34 & 16.35 & 16.34 & 16.34 & 20.03 & 20.07 & 20.06 & 20.05 & 1.68 & 1.66 & 1.65 & 1.66 & 1.07 & 1.08 & 1.07 & 1.07 \\
\hline
\end{tabular}

Çizelge 5. Dut genotiplerinde $\mathrm{pH}$, SÇKM ve TEA değerleri

\begin{tabular}{|c|c|c|c|c|c|c|c|c|c|c|c|c|}
\hline \multirow[b]{2}{*}{ Bitkiler } & \multicolumn{4}{|c|}{$\mathrm{pH}(\%)$} & \multicolumn{4}{|c|}{ SÇKM (\%) } & \multicolumn{4}{|c|}{ TEA (\%) } \\
\hline & 1.yıl & 2.yıl & 3.yıl & Ort. & 1.yıl & 2.yıl & 3.yıl & Ort. & 1.yıl & 2.yıl & 3.yıl & Ort. \\
\hline 1 & 3.45 & 3.43 & 3.45 & 3.44 & 3.45 & 3.43 & 3.45 & 15.97 & 3.45 & 3.43 & 3.45 & 0.22 \\
\hline 2 & 3.39 & 3.39 & 3.40 & 3.39 & 3.39 & 3.39 & 3.40 & 15.44 & 3.39 & 3.39 & 3.40 & 0.23 \\
\hline 3 & 3.37 & 3.36 & 3.35 & 3.36 & 3.37 & 3.36 & 3.35 & 15.40 & 3.37 & 3.36 & 3.35 & 0.24 \\
\hline 4 & 3.42 & 3.44 & 3.44 & 3.43 & 3.42 & 3.44 & 3.44 & 15.20 & 3.42 & 3.44 & 3.44 & 0.22 \\
\hline 5 & 3.41 & 3.45 & 3.43 & 3.43 & 15.95 & 15.85 & 15.85 & 15.88 & 0.25 & 0.22 & 0.22 & 0.23 \\
\hline Ebeveyn & 3.40 & 3.39 & 3.40 & 3.40 & 16.00 & 15.98 & 15.95 & 15.97 & 0.22 & 0.22 & 0.23 & 0.22 \\
\hline
\end{tabular}


Çizelge 6. Dut genotiplerinde kuru madde, kül, protein, ham yağ ve toplam şeker değerleri

\begin{tabular}{|c|c|c|c|c|c|c|c|c|c|c|c|c|c|c|c|c|c|c|c|c|}
\hline \multirow[b]{2}{*}{ Bitkiler } & \multicolumn{4}{|c|}{ Kuru Madde Oranı (\%) } & \multicolumn{4}{|c|}{ Kül Oranı (\%) } & \multicolumn{4}{|c|}{ Protein Oranı (\%) } & \multicolumn{4}{|c|}{ Ham Yağ Oranı (\%) } & \multicolumn{4}{|c|}{ Toplam Șeker Oranı (\%) } \\
\hline & 1.yil & 2.yil & 3.yil & Ort. & 1.yil & 2.yil & 3.yil & Ort. & 1.yil & 2.yil & 3.yil & Ort. & 1.yıl & 2.yıl & 3.yil & Ort. & 1.yil & 2.yil & 3.yıl & Ort. \\
\hline 1 & 18.95 & 18.87 & 18.94 & 18.92 & 3.16 & 3.13 & 3.15 & 3.15 & 3.90 & 3.94 & 3.91 & 3.92 & 5.11 & 5.15 & 5.19 & 5.15 & 15.29 & 15.16 & 15.18 & 15.21 \\
\hline 2 & 18.66 & 18.15 & 18.49 & 18.43 & 3.22 & 3.19 & 3.22 & 3.21 & 3.22 & 3.19 & 3.21 & 3.21 & 5.01 & 4.90 & 4.97 & 4.96 & 15.47 & 15.34 & 15.49 & 15.43 \\
\hline 3 & 18.05 & 18.17 & 18.08 & 18.10 & 3.19 & 3.20 & 3.22 & 3.20 & 3.28 & 3.32 & 3.36 & 3.33 & 5.70 & 5.74 & 5.72 & 5.72 & 13.79 & 13.84 & 13.82 & 14.81 \\
\hline 4 & 18.40 & 18.32 & 18.34 & 18.35 & 3.20 & 3.18 & 3.20 & 3.19 & 3.20 & 3.18 & 3.20 & 3.19 & 5.01 & 5.03 & 5.07 & 5.03 & 15.50 & 15.41 & 15.43 & 15.44 \\
\hline 5 & 18.72 & 18.74 & 18.81 & 18.75 & 3.25 & 3.27 & 3.25 & 3.25 & 3.25 & 3.27 & 3.25 & 3.25 & 5.53 & 5.66 & 5.70 & 5.63 & 13.97 & 13.95 & 13.91 & 14.94 \\
\hline Ebeveyn & 18.46 & 18.49 & 18.51 & 18.48 & 3.22 & 3.24 & 3.24 & 3.23 & 3.22 & 3.24 & 3.24 & 3.23 & 5.32 & 5.34 & 5.37 & 5.34 & 15.16 & 15.27 & 15.36 & 15.26 \\
\hline
\end{tabular}

Çizelge 7. Olgunlaşmış meyvelerde renk değerleri

\begin{tabular}{|c|c|c|c|c|c|c|c|c|c|c|c|c|c|c|c|c|c|c|c|c|}
\hline \multirow[t]{2}{*}{ Bitkiler } & \multicolumn{4}{|c|}{ L } & \multicolumn{4}{|c|}{ a } & \multicolumn{4}{|c|}{ b } & \multicolumn{4}{|c|}{ Kroma } & \multicolumn{4}{|c|}{ Hue } \\
\hline & 1.yil & 2.yil & 3.yil & Ort. & 1.yll & 2.yil & 3.yil & Ort. & 1.yil & 2.yil & 3.yll & Ort. & 1.yIl & 2.yil & 3.yil & Ort. & 1.yıl & 2.yil & 3.yil & Ort. \\
\hline 1 & 18.80 & 18.32 & 18.59 & 18.57 & 5.06 & 5.14 & 5.11 & 5.10 & 5.90 & 5.90 & 5.90 & 5.90 & 7.39 & 7.45 & 7.43 & 7.42 & 46.38 & 48.42 & 47.40 & 47.4 \\
\hline 2 & 18.30 & 18.66 & 18.47 & 18.47 & 5.19 & 5.03 & 5.13 & 5.11 & 5.95 & 5.93 & 5.93 & 5.93 & 7.85 & 7.78 & 7.82 & 7.81 & 49.50 & 49.08 & 49.26 & 49.28 \\
\hline 3 & 18.91 & 19.07 & 18.95 & 18.97 & 5.77 & 5.71 & 5.70 & 5.72 & 5.80 & 5.86 & 5.82 & 5.83 & 9.22 & 9.46 & 9.30 & 9.32 & 44.04 & 43.70 & 43.81 & 43.85 \\
\hline 4 & 18.62 & 18.39 & 18.56 & 18.52 & 5.07 & 5.10 & 5.11 & 5.09 & 5.91 & 5.91 & 5.90 & 5.90 & 7.41 & 7.42 & 7.44 & 7.42 & 46.64 & 48.40 & 47.43 & 47.49 \\
\hline 5 & 18.42 & 18.60 & 18.51 & 18.51 & 5.24 & 5.33 & 5.26 & 5.27 & 5.94 & 5.93 & 5.94 & 5.93 & 7.80 & 7.71 & 7.79 & 7.76 & 47.36 & 47.21 & 47.29 & 47.28 \\
\hline Ebeveyn & 18.74 & 18.46 & 18.50 & 18.56 & 5.16 & 5.13 & 5.22 & 5.17 & 5.93 & 5.93 & 5.92 & 5.92 & 7.61 & 7.66 & 7.63 & 7.63 & 47.38 & 48.09 & 47.26 & 47.57 \\
\hline
\end{tabular}

\section{Sonuç ve Öneriler}

Son yıllarda koyu renkli meyvelerin sağlık açısından çok daha faydalı muhtevaya sahip olduğunun bildirilmesiyle bu türlere karşı ilgi artmıştır. Karadut bu meyve türlerinden birisidir. $\mathrm{Bu}$ çalışma, Kahramanmaraş merkez ilçede yetiştiriciliği yapılan Morus nigra (Karadut) türüne ait halk arasında urmu dutu olarak bilinen genotip ve bu genotipten klonal olarak çoğaltılan verim çağındaki 5 bitkide bazı morfolojik, fenolojik ve pomolojik özelliklerin belirlenmesi amaçlanmıştır. $\mathrm{Bu}$ araştırmanın sonunda urmu dut genotipinin hem bitkisel hem de meyve kalitesi bakımından önemli özelliklere sahip olduğu belirlenmiştir.

Çalışmanın en önemli sonuçlarından biri klonal olarak çoğaltılan bitkilerde gençlik kısırlık döneminin kısa olduğu 3 yıldan itibaren meyveye yattıkları görülmüştür. Klonal çoğaltılan bitkiler ile ana ebeveyn bitkinin özelliklerinin beklenildiği gibi birbirine çok yakın olduğu belirlenmiştir. İnsan beslenmesindeki öneminden dolayı karadut meyvelerine özellikle de meyve suyuna talep artmaktadır. Buda karadut üretimini tetiklemektedir. Yapılan bu çalışma sonucunda urmu dut genotipleri ile rahatlıkla kapama bahçelerinin kurulabileceği görülmüştür.

Teşekkür: Bu çalışma, Türkiye de ilk defa urmu dut genotipini klonal olarak çoğaltarak, bu çalışmanın materyallerini temin eden merhum Prof. Dr. Mehmet Nuri NAS'a ithafen yapılmıştır. Sayın hocamızın ruhu şad olsun.

Çıkar Çatışması Beyanı: Makale yazarları aralarında herhangi bir çıkar çatışması olmadığını beyan ederler.

Araştırmacıların Katkı Oranı Beyan Özeti: Yazarlar makaleye eşit oranda katkı sağlamış olduklarını beyan ederler.

\section{Kaynaklar}

Akbulut, M., Çoklar, H., Çekiç, Ç. 2006. Farklı dut çeşitlerinin bazı kimyasal özellikleri ve mineral madde içeriklerinin belirlenmesi. In: II. Ulusal Üzümsü Meyve Sempozyumu Bildirileri, 14-16 Eylül Tokat, 176-180.

Anonim, 2002. California Rare Fruit Growers, Inc. Index of CRFG Publications, 1969-1989 and Annual Indexes of Fruit Gardener for Additional articles on the Mulberry. (https://www.crfg.org/pubs/ff/mulberry.ht $\mathrm{ml})$.

Bellini, E., Giordani E., Roger J.P. 2000. The mulberry for fruit. II gelso da frutto L'informatore Agrario, Verona, LVI, 7: 89-93.

Cemeroğlu, B. 1992. Meyve ve sebze işleme endüstrisinde temel analiz metotları. Biltav Yayınları, Ankara, 281-282.

Chen, C., You, L. J., Abbasi, A. M., Fu, X., Liu, R. H. 2015. Optimization for ultrasound extraction of polysaccharides from mulberry fruits with antioxidant and hyperglycemic activity in vitro. Carbohydrate Polymers, 130, 122-132.

Çam, ì. 2000. Edremit ve Gevaş yöresi dutlarının fenolojik ve pomolojik özellikleri ile seleksiyonu üzerine araştırmalar. Yüksek Lisans Tezi, Yüzüncü Yıl Üniversitesi, Van.

De Candolle, A. 1967. Origin of cultivated plants. New York and London, p. 149-153.

Erdem, S. 2015. Bulancak karası dutunun bazı meyve özelliklerinin belirlenmesi ve çelikle çoğaltılması üzerine bir araştırma. Yüksek Lisans Tezi, Ordu Üniversitesi, Fen Bilimleri Enstitüsü, Bahçe Bitkileri Anabilim Dalı, 38s.

Erdoğan, Ü., Pırlak, L. 2005. Ükemizde dut (Morus spp.) üretimi ve değerlendirilmesi, Alatarım, 4 (2), 38-43.

Erkaleli, Z.Ö., Dalkılıç, Z. 2016. Uşak ili ulubey ilçesinde yetişen karadutların (Morus nigra 
L.) morfolojik, fenolojik ve pomolojik özelliklerinin belirlenmesi. Adnan Menderes Üniversitesi Ziraat Fakültesi Dergisi, 13 (1), 89-106.

Güven, S., Başaran, M. 1979. Çanakkale yöresinde üretilen karadut (Morus nigra L.) meyvesinin besin teknolojisi yönünden değerlendirilmesi. Tarımsal Araştırma Dergisi, 1 (2), 108-117.

GM de Rougemont, 1989. A field guide to the crops of britain and europe. Collins, 8 Grafton Street, p. 356, London W1.

Hosseini, A.S., Akramian, M., Khadivi, A., SalehiArjmand, H. 2018. Phenotypic and chemical variation of black mulberry (Morus nigra) genotypes. Industrial Crops and Products, 117, 260-271.

Huo, Y. 2004. Mulberry cultivation and utilization in China. Mulberry for Animal Production, FAO Animal Production and Health Paper, 147:11-44

http://www.fao.org/DOCREP/005/X9895E/x 9895e03.htm (21.02.2004)

Koyuncu, F., Vural, E. 2003. Kara Dut (Morus nigra L.) Ağacının bazı organ ve dokularının morfolojik özellikleri. Ulusal Kivi ve Üzümsü Meyveler Sempozyumu, Ordu, 418-423.

Koyuncu, F. 2004. Morphological and agronomical characterization of native black mulberry (Morus nigra L.) in Sutculer, Turkey. Plant Genetic Resources Newsletter.

Lopez, J., Vega Galvez, A., Torres, M.J., Lemus Mondaca, R., Quispe Fuentes, I., Di Scala, K. 2013. Effect of dehydration temperature on physico-chemical properties and antioxidant capacity of goldenberry (Physalis peruviana L.). Chilean Journal of Agricultural Research, 73 (3), 293-300.

Mazza, G., Miniati, E. 1993. Antosiyanins in fruit, vegetabes and grains, CRC Press, Boca Raton, Florida.
McGuire, R.G. 1992. Reporting of objective color measurements. Hort Science, 27, 12541255.

Okatan, V. 2018. Ege Bölgesindeki karadut (Morus nigra L.) genotiplerinin meyvelerindeki fenolik bileşikler ve fitokimyasallar. Folia Horticulturae, 30 (1), 93-101.

Özgen, M., Serçe, S., Kaya, C. 2009. Phytochemical and antioxidant properties of anthocyaninrich Morus nigra and Morus rubra fruits. Scientia Horticulturae, 119 (3), 275-279.

Polat, ì. 2013. Parmak Dutların (Morus laevigata) Fenolojik, pomolojik özellikleri ve olgunlaşma esnasındaki fitokimyasal değişimleri, Gaziosmanpaşa Üniversitesi, Fen Bilimleri Enstitüsü, Bahçe Bitkileri Anabilim Dalı, Yüksek Lisans Tezi, Tokat, 44 s.

Pool, R.J. 1966. Handbook of Nebraska trees. Nebraska Conservation Bulletin, 32, p. 179, Lincoln.

Rahman A.H.M.M., Khanom A. 2013. Taxonomic and ethno-medicinal study of species from Moraceae (Mulberry) family in Bangladesh flora. Res. Plant Sci., 3, 53-57.

Roger, J.P. (2002). Description of mulberry tree, Conservatoire Botanique Noational Mediterraneen de Porquerolles-France. 5 p.

Stoner, G.D., Kresty L.A., Carlton P.S., Siglin J.C., Morse M.A. 1999. Isothiocyanates and freeze-dried strawberries as inhibitors of esophageal cancer. Toxicology Science, 52, 95-100.

Uzun, H., Bayır, A. 2009. Farklı dut genotiplerinin bazı kimyasal özellikleri ve antiradikal aktiviteleri. In: III. Ulusal Üzümsü Meyveler Sempozyumu Bildileri, 1012 Haziran 2009, Kahramanmaraş.

Vavilov, N.I. 1926. The origin of cultivated plants. Bulletin of Applied Botany, 16 (2), 392-393. 